\title{
REVIEW
}

\section{Ferraris for All: In Defence of Economic Progress}

\author{
Daniel Ben-Ami \\ Bristol: Policy Press, 2010, 282pp, £18.99 (hbk) \\ ISBN 9781847423467
}

\author{
Ed Ferrari* \\ University of Sheffield
}

\begin{abstract}
I always knew that the editors of People, Place and Policy Online had a good sense of humour, but when I was asked to review Ferraris for All I thought they had allowed the opportunity for a joke to trump their better editorial sense. I stand happily corrected, for Ferraris for All is a timely book on a matter of great importance, and it absorbed me thoroughly. That's not to say it is without its faults, of which I found many. But it is always good to sharpen one's own capacities by engaging with an argument that one has an innate scepticism of. In this case the argument is that economic growth is good for us, individually and as a society.
\end{abstract}

Following an introductory chapter, the book is structured into two parts. The first part comprises four chapters in which the author reviews the various elements of what he contends is the "prevalent mood" (p. 2) of growth scepticism. This comes as a surprising contention, given that national and international economic policy often appears to be dominated by a drive for growth: the current epoch being a case in point. He uses this first part to offer a deconstruction of growth scepticism which, for him, ranges from the clear anti-growth positions of 'deep green' environmentalists and supporters of décroissance ('degrowth') to milder forms he finds are widely held within mainstream politics and economics. The second part of the book is essentially where Ben-Ami's message comes in: it is, over five chapters, his "rejoinder to the growth sceptics" (p. xi). Before I go on to say a bit more about Ben-Ami's arguments, I will take the opportunity to air my first grievance with the book.

The structure of the book - particularly the division into two parts, anti- and progrowth arguments - is frustrating. In using the first part of the book almost exclusively to tee up his own rejoinder, through his lengthy discussion of various critiques of economic growth, the author offers little by way of immediate riposte. The reader is left wanting. It is a bit like a courtroom barrister saving his stinging, critical denouement until the very last moment. The effect is that the reader knows something is coming, but knows not what. To me, rather than careful argumentation, it came across as posturing and I would have much preferred the author to get on with his counterarguments so that I could more effectively develop my own line of reasoning through reading. This is no thrilling page-turner and didn't need to be written 
like this. This gripe aside, the structure does at least allow remarkable clarity in the book's overall messages, even if to read it is to feel like undergoing a form of thought manipulation.

So, what of the first section, in which the dominant mode of growth scepticism, of which we all seem guilty, is laid bare? Over the course of four chapters, Ben-Ami explains how such scepticism developed and how it is manifest throughout contemporary economic and political thought.

After an effective introduction, chapter two takes us through the contributions of early scholars and attempts to position them. In particular, it charts the Enlightenment and the emerging belief in scientific reason as one of the keys to social progress, and it reminds us of the essential concerns of Adam Smith and David Ricardo with economic growth as an important goal. There is a useful review of various ways in which scholars have tried to conceptualise 'progress', and these are contrasted sharply against Malthusian notions of population crisis (i.e., a population unable to feed itself) and the emergence of 'deep green' positions. With this first chapter, Ben-Ami essentially provides us with the two poles between which we can position the arguments in the rest of the book.

Chapters three and four examine the forms that growth scepticism takes more closely. First, the author catalogues the various forms of scepticism, including the environmental (Meadows et al., 1972), social (Hirsch, 1976) and, more recently, moral (e.g. Klein, 2000) limits of growth; the setting of these often contested and/or transcendental normative limits; and alternative conceptualisations of progress and sustainability. Chapter four extends this analysis into the realm of class strategies and explores how elites can sometimes use growth scepticism to justify the maintenance of their own positions. Ben-Ami cites elites' (broadly, middle classes') desires to check mass consumption in order to defend a privileged lifestyle.

Chapter five looks at how political notions of progress have switched. Ben-Ami contends that a concern for social and economic progress was once a concern of the left, albeit one couched in terms of the expansion of popular prosperity (e.g. through redistributive mechanisms and Marxist flavours of growth). He then shows how progress became the preserve of the pro-market right, this time through different mechanisms and with a different conceptualisation of the growth ideal. The turnaround was associated with what Ben-Ami terms the rise of growth scepticism among the left a product, he argues, of the pessimism of mankind to work for its own good following the events of the early 20th Century (depression, war, Holocaust), the rise of a culture of fear and risk averseness, economic crises and deindustrialisation. Interestingly, BenAmi's analysis goes far beyond the role of environmentalism in developing growth scepticism. This is a major point of debate.

The second part of the book contains Ben-Ami's rejoinder to his own treatment of growth scepticism contained in part one. In some ways it is less authoritative in tone, but far more polemic, than part one. Early in chapter six there is the obligatory inventory of products that denote economic advance. This reminded me of a scene from Bill Forsyth's corporate/environmental comedy film Local Hero (1983). Two oil execs walk along an idyllic beach (soon to be an oil refinery) in Scotland and ask each other, "could you imagine a world without oil? No automobiles, or paint. Or polish. No ink and nylon. No detergents and Perspex ..." The irony was that the scene, as framed, made it perfectly possible for a fleeting moment to imagine a world without those things. As the execs later learned, it was all a question of relativities and priorities. It is hard to deny that the products of growth and innovation are in themselves good - but the bigger picture is surely the impact they have on our own patterns of consumption and what motivates them, and the question of inequalities and social justice. 
At this stage in the book, Ben-Ami rather underplays the importance of the latter, save for the rather problematic assertion that it would be unjust not to strive for progress because something more is better than nothing more. This brings us back to relativities again, this time temporally. We are able to look to the past and judge it against the present simply because we have a history. But if we were living in 1900 it would not matter that we did not have mobile phones, and all the other trappings of modern life that for Ben-Ami constitute the wondrous fruit of growth, because they were not yet invented. Consequently, our whole society and economy would not revolve around those inventions. Ben-Ami ought to try putting on Rawls' (1971) 'veil of ignorance' some time, because it is otherwise very easy to fall into the trap of holding up advanced medicine, leisure time and the internet as of obvious value without really interrogating why this might be case, and whether it applies to everybody everywhere equally. As Wilkinson and Pickett (2009) note, there's a point beyond which striving for more absolute increases in living standards becomes futile: Ben-Ami responds by saying we're all living longer; it doesn't matter that the gaps are getting bigger. Perhaps it's a question of the geographic scale of our worldview, but the biggest frustration with Ben-Ami's book is its blind faith in trickle-down economics.

Chapter seven is where the book really starts to get controversial. It tackles the issue of environmentalism and its links to anti-growth stances. In this chapter, the author restates many of common gripes held against environmentalism. He wonders, for example, about the practical effect of recycling and switching off electrical devices when not in use. He places faith in market incentives and technology to push back the dates at which resource depletion will likely occur. The problems of environmental inequality, he argues, will become irrelevant as growth and technology will in time lead to the solution. Thus China will eventually be able to enjoy clean air in the same way that the UK now does despite it producing more cars (for example) than it ever did before. This of course rather supposes a major power shift: that the rapidly industrialising nations will not only become the pre-eminent workshops of the world, but will be able to develop the political and democratic structures that will ensure that their global role is not simply one of cheap production and economic servitude. But such questions about the relationships between Western elites and emerging democracies, and between state and market, go unanswered in this book, which is a great shame.

By chapter eight, the book has begun to engage with some of the more deep-rooted philosophical issues underpinning our views on economic growth: the nature of happiness, for example. Some time is spent on the apparent malady of 'affluenza': the idea - which Ben-Ami is unconvinced by - that consumerism can literally make us ill. There is some interesting material here, including a fascinating, but probably partial, deconstruction of the empirical treatment of happiness. Essentially, Ben-Ami concludes that happiness as an objective is ultimately limiting and robs us of the capacity for more fulfilling and sophisticated goals. In this sense it is innately conservative. It is an interesting chapter, but Ben-Ami would have done well to engage with some of the recent work on happiness that develops a specifically spatial dimension (e.g. Ballas, 2007; Stanca, 2010) because this would have provided a connection with the issue of uneven economic development.

Chapter nine begins to round off the book by tackling the issue of inequality. The perspective taken is essentially about global inequalities, poverty and questions of international development. He dismisses as 'therapeutic' the dominant form of international development, which focuses on extending capacities and taking a holistic view of needs as proposed by the likes of Amartya Sen. A material approach to development is instead needed, even if inequalities may be inherent to this: 
It is hard to imagine substantial improvement in the living standards of the poorest without a broader process of economic change. And market economies, for better or worse, tend to have a high level of inequality embedded in their structure (p. 211).

By this time it is clear that the argument is essentially definitional: what matters more: Absolute living standards or relative inequalities? I was mildly disappointed that the book did not also consider what is happening within countries and cities, since these represent a more controlled environment for examining the implications of economic change.

The book concludes with a ten-point manifesto for change. Some of the points are well made and broadly supported by the book's analysis, but others seem more of a stretch. One has to admire Ben-Ami's optimism about human capacity and innovation. Whether it is shared by all is another matter. Specific points that are more controversial include the need to generate massive amounts of cheap energy, presumably using nuclear fuel; and the need to accept (and embrace) humankind's superiority over nature and desire to shape it. Given the potentially massive ramifications of these positions I would want to see more evidence and better argumentation before adopting them.

This is a fun book and quite easy to read. It is nicely produced and well written, although the occasional journalistic flourish can annoy - this extends to the title, which is really quite misleading (a point at least recognised by the author): the book's argument is not about conspicuous consumption per se but mass participation in economic growth.

Ultimately, for many readers, I suspect that the subject matter will irritate and illuminate in equal measure. When illumination occurs it is often the inconsequential as much as the substantive upon which light is cast: I now know more about Prince Charles' dental care (p. 65) and 1970s disaster movies (p. 49) than I considered necessary. That aside, the book is provocative and worth reading. Whether I can recommend it as a serious contribution to the key debates concerning the desirability and impacts of economic growth is far less certain.

* Correspondence address: Ed Ferrari, Department of Town and Regional Planning, University of Sheffield, Western Bank, Sheffield S10 2TN. Email: e.t.ferrari@sheffield.ac.uk.

\section{References}

Ballas, D. (2007) Exploring geographies of happiness in Britain and the implications for public policy. Mimeo. Available at http://www.uptap.net/project10.html

Hirsch, F. (1976) Social Limits to Growth. London: Routledge and Kegan Paul.

Klein, N. (2000) No Logo. London: Flamingo.

Meadows, D.H., Meadows, D.L., Randers, J. and Behrens, W.W. (1972) The Limits of Growth. New York: Signet.

Rawls, J. (1971) A Theory of Justice. Harvard, MA: Belknap Press.

Stanca, L. (2010) The geography of economics and happiness: spatial patterns in the effects of economic conditions on well-being. Social Indicators Research, 99,1, 115-133.

Wilkinson, R. and Pickett, K. (2009) The Spirit Level: why equality is better for everyone. Harmondsworth: Penguin. 